\title{
CHANGES IN CARE MANAGEMENT AFTER "FAST TRACK" PROTOCOL INTRODUCTION FOR HIP FRACTURE PATIENTS
}

\author{
Paulius Dobožinskas $^{1}$, Rasa Valavičienè $^{2}$, Ami Hommel ${ }^{3}$ \\ ${ }^{1}$ Lithuanian Medicine academy University of Health Sciences, \\ ${ }^{2}$ Kaunas College University of Applied Sciences, \\ ${ }^{3}$ Lund University, Lund University Hospital, Department of Orthopedics, Sweden
}

Key words: hip fracture, fast track protocol, patients care.

\begin{abstract}
Summary
Background and objective. The introduction of fast track schemes for patients with hip fracture usually results in reductions in length of stay and mortality, and reduces the numbers of complications. The aim of this study was to evaluate the changes in procedure performance, time from admission to surgery and length of stay after introduction of the fast track protocol (FTP).

Materials and methods. 235 patients with hip fracture treated before FTP introduction and after the introduction were prospectively investigated. We studied the use of fracture immobilization, analgesics, infusion therapy, blood test sampling and ECG registration during these two periods. Information about the mean/median time period from admission to surgery and length of stay in the hospital (LOS) in the orthopaedic department was recorded. Results. Significant improvements in the use of ims mobilization, infusion therapy, blood test sampling and ECG recording were observed after FTP introduction. Also significant reductions were observed in both waiting time for surgery and for LOS.

Conclusion. Introduction of a FTP improved the use of procedures necessary for hip fracture patient care, while reducing wait to surgery time and LOS.
\end{abstract}

\section{Introduction}

Hip fracture is the most severe complication of osteoporosis and, despite being a frequent health problem, there is wide variability in both the health care provided to this patient group and the results achieved after their treatment. Clinical guidelines based on scientific research are a tool that helps to reduce this variability. Hospitals in several countries have adopted well-defined hip fracture patient care pathways [1-6]. These care pathways include detailed descriptions of all procedures for hip fracture patient care from admission to discharge. The introduction of fast track schemes usually results in reductions in length of stay and mortality, and reduces the numbers of complications [7-10].

In a previous study we compared hip fracture patients treated in a Lithuanian institution, where no special care program was introduced [11] with patients treated in a University hospital in Sweden where a fast track pathway was introduced five years ago. The analysis included an audit of hip fracture patients' care during their admission; stay in Acute \& Emergency department (A\&E) and in the orthopaedic ward. The previous study [11] showed some potential benefits using the hip fracture care pathway, which was particularly associated with shorter time to surgery, thus reducing the risk of complications. Based on the audit results a Fast track protocol (FTP) was introduced for hip fracture patients treated at one institution in Lithuania.

The aim of the current study was to evaluate the changes in procedure performance, time from admission to surgery and length of stay after introduction of the fast track protocol.

\section{Patients and methods}

235 patients with hip fracture treated during two different time periods were prospectively investigated. Patients who died in the institution or not operated on due to medical reasons were not included in this study. Before the FTP introduction, from January 1, 2009 to June 30, 2010, 97 hip fracture patients were included as a control group (CG). After the fast track protocol was introduced in 2011, the data were compared with an intervention group (IG) of 138 hip fracture patients admitted during June $1^{\text {st }}, 2011$-May $31^{\text {th }}, 2012$. 
Prior to fast track introduction, a number of team meetings were conducted and problems in care, identified in a previous hip fracture audit study, were discussed. A certain number of procedures were recognized to be of importance in hip fracture management and were modified accordingly for subsequent investigation. The study was focused on the completion of all investigated procedures and their effect on the time period from admission to surgery and length of stay (LOS). Just before the fast track protocol was introduced, all ambulance services were informed about the study and encouraged to transport more patients with suspected hip fracture to our institution.

The FTP included well-defined care in the A\&E department and orthopaedic ward as well as the protocol for planning a surgery within 24 hours after admission. After the arrival of patients with a suspected hip fracture he/she was transported directly to the X-ray department. If the hip fracture diagnosis was confirmed, the patient was returned to the A\&E where pain evaluation and subsequent drug prescription, immobilization, infusion therapy, electrocare

Table 1. The baseline data of study groups before and after „Fast track protocol" introduction.

ASA - American Society of Anesthesiologists

\begin{tabular}{|c|c|c|c|}
\hline Characteristic & $\begin{array}{c}\text { Before pro- } \\
\text { tocol intro- } \\
\text { duction, } \\
\text { n=97 (\%) }\end{array}$ & $\begin{array}{l}\text { After pro- } \\
\text { tocol intro- } \\
\text { duction, } \\
\text { n=138(\%) }\end{array}$ & $\begin{array}{c}\mathbf{p} \\
\text { value }\end{array}$ \\
\hline $\begin{array}{rr}\text { Gender } & \text { Male } \\
& \text { Fe- } \\
& \text { male } \\
\end{array}$ & $\begin{array}{l}25(25.8) \\
72(74.2)\end{array}$ & $\begin{array}{l}42(30.4) \\
96(69.6)\end{array}$ & 0.47 \\
\hline $\begin{array}{l}\text { Age } \\
\text { Median } \\
\text { Range (years) }\end{array}$ & $\begin{array}{c}77.2 \\
79 \\
51-101 \\
\end{array}$ & $\begin{array}{c}78.5 \\
81 \\
28-97 \\
\end{array}$ & 0.08 \\
\hline $\begin{array}{lc}\text { ASA grade } & \text { I } \\
& \text { II } \\
& \text { III } \\
& \text { IV }\end{array}$ & $\begin{array}{c}2(2.1) \\
53(54.6 .) \\
40(41.2) \\
2(2.1)\end{array}$ & $\begin{array}{c}5(3.6) \\
44(31.9) \\
84(60.9) \\
5(3.6)\end{array}$ & 0.007 \\
\hline $\begin{array}{l}\text { Type of fracture } \\
\text { - Undisplaced intra- } \\
\text { capsular } \\
\text { - Displaced intra- } \\
\text { capsular } \\
\text { - Basocervical } \\
\text { - Trochanteric } \\
\text { - Subtrochanteric }\end{array}$ & $\begin{array}{c}5(5.2) \\
92(94.8) \\
0 \\
0 \\
0\end{array}$ & $\begin{array}{c}6(4.3) \\
77(55.8) \\
11(8) \\
40(29) \\
4(2.9)\end{array}$ & $\begin{array}{c}< \\
0.001\end{array}$ \\
\hline $\begin{array}{l}\text { Type of surgery } \\
-3 \text { or more screws } \\
-1 \text { screw and plate } \\
- \text { Total hip arthro- } \\
\text { plasty }\end{array}$ & $\begin{array}{c}0 \\
1(1) \\
96(99)\end{array}$ & $\begin{array}{c}6(4.4) \\
43(31.2) \\
89(64.4)\end{array}$ & $<0.001$ \\
\hline
\end{tabular}

diography (ECG) and blood tests were performed. Within two hours from admission the patients were supposed to be transported to the orthopaedic ward. Within one hour in the orthopaedic ward the patient met an anaesthetist, who decided on the timing surgery, with the aim of operating on the patient within the shortest possible time. Any reasons for delaying surgery should be clearly defined and recorded in the patient's case history.

We studied the use of fracture immobilization, analgesics, infusion therapy, blood test sampling, American Soi ciety of Anesthesiologists (ASA) grade (ASA I= Normal healthy individual, ASA II Mild systemic disease that does not limit activity, ASA III = Severe systemic disease that limits activity but is not incapacitating ASA IV= Incapacitating systemic disease which is constantly life-threatening) and ECG registration before and after FTP introduction. Furthermore, information about the mean/median time period from admission to surgery and LOS in the orthopaedic department was recorded. The study was approved by the ethics committee of the institution.

Statistics. Data are presented as mean \pm standard deviation (SD) and as median and range. To determine whether our data were normally distributed, we performed the Shapiro-Wilk normality test. Measurements between groups were compared using nonparametric Mann-Whitney U tests. The chi square test was used to compare the proportions between the groups. A p-value of $<0.05$ was considered significant. SPSS software was used for the calculations.

\section{Results}

The baseline data for the treated patients is presented in Table 1. There were no significant differences between CG and IG regarding age and gender.

Table 2. Interventions, performed during patients' hospitalization period before and after „Fast track protocol“" introduction.

\begin{tabular}{|l|c|c|l|}
\hline Intervention & $\begin{array}{c}\text { Before pro- } \\
\text { tocol intro- } \\
\text { duction, } \\
\mathbf{n = 9 7} \mathbf{9 \% )}\end{array}$ & $\begin{array}{c}\text { After pro- } \\
\text { tocol intro- } \\
\text { duction, } \\
\mathbf{n = 1 3 8} \mathbf{( \% )}\end{array}$ & p value \\
\hline Analgesia: used & $59(60.8)$ & $87(63)$ & 0.3 \\
\hline $\begin{array}{l}\text { Immobilization } \\
\text { performed }\end{array}$ & $8(8.2)$ & $94(68.1)$ & $<0.001$ \\
\hline Infusiotherapy used & $23(23.7)$ & $74(53.6)$ & $<0.001$ \\
\hline $\begin{array}{l}\text { Blood test perfor- } \\
\text { med }\end{array}$ & $4(4.1)$ & $129(93.5)$ & $<0.001$ \\
\hline $\begin{array}{l}\text { Electrocardiography } \\
\text { registered }\end{array}$ & $10(10.3)$ & $102(73.9)$ & $<0.001$ \\
\hline
\end{tabular}


However, differences were observed in fracture type between the groups. After the intervention, a significantly higher number of patients with trochanteric and subtrochanteric fractures were treated in the institution but the number of undisplaced hip fractures remained similar. The higher number of patients with trochanteric fractures in the intervention group resulted in differences being observed in the treatment methods used on both groups of patients (a higher proportion of patients were treated with osteosynthesis in the IG as compared to a higher proportion of patients treated with THA in the CG. In addition, more patients in the IG had a higher ASA grade.

A comparison of procedures performed between the groups is presented in Table 2 .

The use of pain relievers did not differ significantly between CG and IG. But significant improvements in the use of immobilization, infusion therapy, blood test sampling and ECG recording were observed in the IG.

Changes in waiting time to surgery and LOS in CG and IG are presented in table 3. Significant reductions were observed in both waiting time for surgery and for LOS in the IG. A separate analysis of THA (Total Hip Arthroplasty) patients in CG (96) and IG (89), showed a significant reduction in waiting time to surgery (median 44.5 versus 19 hours, $\mathrm{p}<0.001$ ) and LOS (median 11 versus 9 days $(p=0.02)$ in the IG.

Significant reductions were observed in both waiting

Table 3. Changes in waiting time to surgery and length of stay period before and after „Fast track protocol“ introduction.

$A \& E-$ Acute and Emergency.

LOS - Length of stay.

CI-Confidence interval

\begin{tabular}{|c|c|c|c|}
\hline Time periods & $\begin{array}{c}\text { Before pro- } \\
\text { tocol intro- } \\
\text { duction, } \mathbf{n = 9 7}\end{array}$ & $\begin{array}{c}\text { After protocol } \\
\text { introduction, } \\
n=138\end{array}$ & p value \\
\hline $\begin{array}{l}\text { Waiting time in } \\
\text { A\&E room (min.) } \\
\text { Mean } \\
\text { Range (min.) } \\
\text { Median (95CI } \\
(\text { min.)) }\end{array}$ & $\begin{array}{c}150 \\
40-320 \\
130(110-182)\end{array}$ & $\begin{array}{c}90 \\
30-250 \\
50(30-68)\end{array}$ & $<0.02$ \\
\hline $\begin{array}{l}\text { Waiting time to } \\
\text { surgery (h) } \\
\text { Mean } \\
\text { Range (h) } \\
\text { Median (95CI (h)) }\end{array}$ & $\begin{array}{c}64 \\
2-355 \\
44(25-68) \\
\end{array}$ & $\begin{array}{c}39 \\
1-385 \\
17(11-19) \\
\end{array}$ & $<0.001$ \\
\hline $\begin{array}{l}\text { LOS } \\
\text { Mean } \\
\text { Range (h) } \\
\text { Median }(95 \mathrm{CI}(\mathrm{h}))\end{array}$ & $\begin{array}{c}11.5 \\
6-43 \\
11(9-11)\end{array}$ & $\begin{array}{c}10 \\
3-23 \\
9(8-10)\end{array}$ & 0.02 \\
\hline
\end{tabular}

time for surgery and for LOS in the IG. A separate analysis of THA (Total Hip Arthroplasty) patients in CG (96) and IG (89), showed a significant reduction in waiting time to surgery (median 44.5 versus 19 hours, $\mathrm{p}<0.001$ ) and LOS (median 11 versus 9 days $(\mathrm{p}=0.02)$ in the IG.

We investigated the relation between ASA grade, waiting time to surgery and LOS for all 235 patients. The four ASA classes were grouped into two groups (ASA I and II to group 1, ASA III and IV to group 2). We found that group 1 (104) had a median waiting time to surgery of 23 hours (1-254) and 9 (3-43) days LOS. In group 2 (131), the median waiting time to surgery time was 23 hours (1-285), and 10 (4-41) days LOS. The difference between the two ASA groups was significant for LOS $(p=0.006)$, but the difference in waiting time to surgery time was not significant $(p=0.2)$. In a separate analysis of patients in the CG we found that for ASA group 1 the median waiting time to surgery was 28 hours (2-166), and 9 days (4-43) LOS, compared to 70 hours $(3-355), \mathrm{p}=0.02$, and 13 days LOS (6-41), $\mathrm{p}=0.01$ for patients in ASA group 2. Furthermore, for patients after intervention in ASA group 1 the median waiting time to surgery was 12 hours (1-254), and 8 days (3-20) LOS as compared to 18 hours (1-385), $\mathrm{p}=0.1$, and 9 days (4-23), $\mathrm{p}=0.06$ for ASA group 2.

\section{Discussion}

After the introduction of the FTP we observed a significant improvement in the use of immobilization, infusion therapy, blood test sampling and ECG recording. Immobilization of the fracture reduces hip joint pain and prevents further fracture dislocation. The use of infusion therapy also improves the hemodynamic condition of patients and stops the catabolic process [12]. Blood test sampling, ECG recording and coordinated work in the A\&E department resulted in significant reductions in the time spent in the A\&E. Reducing the time spent in the A\&E, according to many authors investigating the effect of introducing FTP, is recognized as an important issue and is in accordance with UK Audit Commission, which determined a target of admission to the ward from A\&E within 1 hour for hip fracture patients $[13,14,15]$. One of the aims of the FTP introduction in our institution, to decrease the time spent in the A\&E by up to two hours was successful; however, there is still room for further improvement.

Fast-tracking systems have been developed to shorten the time from admission to surgery $[16,17,18]$. In our study the median time from admission to surgery was 17 hours in the IG as compared to 44 hours in the CG. It is recognized in the literature that a shorter time period between admission and surgery results in decreased mortality and compli- 
cation rates $[19,20]$. A systematic review and meta-analysis of 16 observational studies investigating a total of 13,478 patients addressed the impact of the timing of surgery on complications and mortality after hip fracture. Early surgery (i.e., within the cut-off limits of 24,48 or 72 h) was associated with a significant reduction in mortality of $19 \%$ (adjusted risk ratio (RR) $0.81,95 \%$ confidence interval (CI) 0.68-0.96) and the incidence of in-hospital complications [21]. Several national institutions recommend that hip-fracture patients should undergo surgery on the day of admission or no later than 24 hours $[13,22]$.

In the CG only one patient was treated with osteosynthesis as compared to 49 patients in the IG, who were mainly patients with trochanteric fractures. The increased number of patients with trochanteric fractures was the result of information provided to the ambulance services regarding the new care protocol introduction, with encouragement to transport all patients with suspected hip fracture to the institution. One may suspect that the differences in type of fracture and treatment methods could have an effect on waiting time to surgery, but a separate analysis of the THA patients comparing both groups showed similar results to those of the whole group.

It has been reported that an optimized hip fracture care program reduces the LOS [23] in the hospital. In our data we found a significant reduction in LOS in the IG as compared to CG. This is in accordance with the majority of literature reports $[9,19]$ investigating the effect of fast track care for hip fracture patients.

ASA grade has been recognized as a factor significantly affecting complication rates and prolonging wait time for surgery due to the need for the medical attention required to prepare the patient for surgery [24]. In our data we observed a significantly greater waiting time to surgery for patients in the CG with ASA grades III and IV as compared to patients with ASA I and II grade. However, while investigating the IG, no significant difference was observed in surgery waiting times between ASA III, IV and ASA I, II grade patients. According to our study results the introduction of the FTP for hip fracture patients eliminated the effect of ASA grade on waiting time to surgery.

The drawback of our current study is that we did not record the rate of complications; thus, we cannot estimate if the faster time to surgery for ASA III and IV grade patients increased the number of adverse event. Thus, further studies are required on this issue to determine if rapid time to surgery on hip fracture patients with a great number of co morbidities will not increase the number of complications postoperatively.

\section{Conclusion}

We conclude that introduction of a fast track protocol improved the use of procedures necessary for hip fracture patient care, while reducing waiting to surgery time and LOS.

\section{References}

1. Cheah J. Development and implementation of a clinical pathway programme in an acute care general hospital In Singapore. International Journal for Quality in Health Care 2000;5(12):403-412. http://dx.doi.org/10.1093/intqhe/12.5.403

2. Hughes K, Coulson D, Bray J. The effectiveness of implementing a care pathway for femoral neck fracture in older people: a prospective controlled before and after study. Age Ageing 2004;33:178-184.

http://dx.doi.org/10.1093/ageing/afh063

3. Gholve PA, Kosygan KP, Sturdee SW, Faraj AA. Multidisciplinary integrated care pathway for fractured neck of femur. A prospective trial with improved outcome. Injury 2005;36(1):93-8.

4. Olsson LE., Karlsson J, Ekman I. The integrated care pathway reduced the number of hospital days by half: a prospective comparative study of patients with acute hip fracture. J Orthop Surg Res 2006;25,1:3.

5. Hommel A. Improved safety and quality of care for patients with a hip fracture, Doctoral dissertation, Lund University 2007.

6. Patel NK, Sarraf KM, Joseph S, Lee C, Middleton F.R. Implementing the National Hip Fracture Database: An audit of care. Injury 2013;44(12):1934-9. http://dx.doi.org/10.1016/j.injury.2013.04.012

7. Foss NB, Kehlet H. Mortality analysis in hip fracture patients: implications for design of future outcome trials. Br J Anaesth 2005;94(1):24-9.

http://dx.doi.org/10.1093/bja/aei010

8. Hommel A, Ulander K, Bjorkelund K, Norrman P, Wingstrand $\mathrm{H}$, Thorngren K. Influence of optimised treatment of people with hip fracture on time to operation, length of hospital stay, reoperations and mortality within 1 year. Injury 2008;39 (10), 1164-1174.

http://dx.doi.org/10.1016/j.injury.2008.01.048

9. Larsson G, Holgers KM. Fast-track care for patients with suspected hip fracture. Injury 2011;42(11):1257-61. http://dx.doi.org/10.1016/j.injury.2011.01.001

10. Kristensen MT, Kehlet H. Most patients regain prefracture basic mobility after hip fracture surgery in a fast-track programme. Dan Med J 2012;59(6):4447.

11. Valavičienė R, Macijauskienè J, Smailys A, Hommel A. The comparison of hip fractures care in Lithuania and Sweden. International Journal of Orthopaedic and Trauma Nursing 2012;16(1),47-52. 
http://dx.doi.org/10.1016/j.ijotn.2011.07.002

12. Tierney A.J. Undernutrition and elderly hospital patients: a review J. Adv. Nurs 1996;228-236. http://dx.doi.org/10.1111/j.1365-2648.1996.tb02661.x

13. New Zealand Guidelines Group. Acute management and immediate rehabilitation after hip fracture amongst people aged 65 years and over. (2003) Available from: http://www.nzgg.org. nz/library_resources/6_hip_fracture_management_guideline.

14. Simunovic N, Devereaux P.J, Bhandari M. Surgery for hip fractures: Does surgical delay affect outcomes? Indian J Orthop 2011;27-32.

http://dx.doi.org/10.4103/0019-5413.73660

15. Orimo H, Nakamura T, Hosoi T, Iki M, Uenishi K, Endo N, et al. Japanese 2011 guidelines for prevention and treatment of osteoporosis - executive summary. Arch Osteoporos 2012;3-20. http://dx.doi.org/10.1007/s11657-012-0109-9

16. Ryan J, Ghani M, Staniforth P, Bryant G, Edwards S."Fast tracking" patients with a proximal femoral fracture. Journal of Accident and Emergency Medicine 1996; 108-110.

http://dx.doi.org/10.1136/emj.13.2.108

17. Rajmohan B. Audit of the effect of a fast tracking protocol on transfer time from $A \& E$ to ward for patients with hip fractures. Injury 2000;585-5896.

http://dx.doi.org/10.1016/S0020-1383(00)00056-5

18. Dinah A.F. Reduction of waiting times in A\&E following introduction of "fast-track" scheme for elderly patients with hip fractures. Injury 2003;34(11):839-41.

http://dx.doi.org/10.1016/S0020-1383(03)00030-5

19. Eriksson M., Kelly-Pettersson P, Stark A, Ekman AK, Sköldenberg O. 'Straight to bed' for hip-fracture patients: a prospective observational cohort study of two fast-track systems in 415 hips. Ann R Coll Surg Engl 2012;94(4):267-71.

http://dx.doi.org/10.1016/j.injury.2012.05.017

20. Westberg M, Snorrason F, Frihagen F. Preoperative waiting time increased the risk of periprosthetic infection in patients with femoral neck fracture. Acta Orthopaedica 2013;84(2):124-9. http://dx.doi.org/10.3109/17453674.2013.775044

21. Simunovic N, Devereaux PJ, Sprague S, Guyatt GH, Schemitsch E, Debeer J, Bhandari M. Effect of early surgery after hip fracture on mortality and complications: systematic review and meta-analysis CMAJ. 2010;1609-1616.

22. Swedish National Board of Health and Welfare. National guidelines for care and treatment of hip fractures [Socialstyrelsens riktlinjer för vård och behandling av höftfraktur]. The National Board of Health and Welfare, Stockholm (2003) Available from: http://www.socialstyrelsen.se/Lists/Artikelkatalog/Attachmen ts/10573/2003-102-1_20031022.pdf, [in Swedish].
23. Pedersen SJ, Borgbjer FM, Schousboe B, Pedersen BD, Jørgensen HL, Duus BR, Lauritzen J.B. A comprehensive hip fracture program reduces complication rates and mortality. $\mathrm{J}$ Am Geriatr Soc 2008; 1831-8. http://dx.doi.org/10.1111/j.1532-5415.2008.01945.x

24. Clague JE, Craddock E, Andrew G, Horan MA, Pendleton N. Predictors of outcome following hip fracture. Admission time predicts length of stay and in-hospital mortality. Injury 2002;33(1):1-6.

http://dx.doi.org/10.1016/S0020-1383(01)00142-5

\section{PACIENTŲ, PATYRUSIỤ ŠLAUNIKAULIO LŪŽİ, PRIEŽIŪRA İDIEGUS "SKUBAUS PACIENTU STACIONARIZAVIMO IR GYDYMO PROTOKOLĄ" P. Dobožinskas, R. Valavičienė, A. Hommel}

Raktažodžiai: šlaunikaulio lūžis, „Fast track“ protokolas, pacientų priežiūra.

Santrauka

Skubaus pacientų stacionarizavimo ir gydymo protokolu (SPSGP) įdiegimas ligoninėse, kuriose teikiama pagalba proksimalinès šlaunikaulio dalies lūžius patyrusiems pacientams, dažniausiai susijęs su gulëjimo ligoninèje laiko sutrumpèjimu, mažesniu pooperacinių komplikacijų skaičiumi ir mirštamumo sumažejjimu.

Atlikto tyrimo tikslas - ivvertinti, kaip pakito proksimalinès šlaunikaulio dalies lūžị patyrusių pacientų priežiūra, laikas nuo atvykimo ị gydymo ịstaigą iki operacijos ir gydymo ligoninèje trukmè ịdiegus „Skubaus pacientų stacionarizavimo ir gydymo protokolą“.

Metodika. İ tyrimą ịtraukti 235 pacientai, patyrę proksimalinị šlaunikaulio lūžị. Iki protokolo įdiegimo ir po protokolo įdiegimo vertinta, ar buvo ịmobilizuota lūžusi galūnè, taikomas nuskausminimas, infuzinè terapija, registruojama elektrokardiograma ir atliekami kraujo tyrimai. Papildomai registruotas laikas nuo paciento atvykimo ị ligoninę iki operacijos bei gulejimo ligoninèje trukmè.

Rezultatai. Lyginant laikotarpi iki ir po protokolo įdiegimo nustatyta, kad reikšmingai dažniau po protokolo įdiegimo buvo įmobilizuojama traumuota galūnè, atliekama infuzinè terapija, kraujo tyrimai ir registruojama elektrokardiograma. Taip pat po protokolo ịdiegimo reikšmingai sutrumpejjo laikas nuo paciento atvykimo ị gydymo ịstaigą iki operacinio gydymo bei gulejjimo ligoninèje trukmè.

Išvada. Skubaus pacientų stacionarizavimo ir gydymo protokolo įdiegimas reikšmingai padidino būtinų procedūrų atlikimo dažni ir sutrumpino laiką iki operacijos bei gulèjimo ligoninèje trukmę.

Adresas susirašinėti: rasa.valaviciene@gmail.com

Gauta 2015-08-17 